\title{
LINK BETWEEN ELEVATED LOCOMOTOR ACTIVITY AND THE SPIKE BURSTING OF ANTENNAL THERMOSENSITIVE NEURONS IN THE CARABID BEETLE PTEROSTICHUS OBLONGOPUNCTATUS
}

\author{
Karin Nurme ${ }^{1}$, Anne Must ${ }^{2}$ and Enno Merivee ${ }^{3}$ \\ Institute of Agricultural and Environmental Sciences, Estonian University of Life Sciences \\ Kreutzwaldi Street 1a, 51014 Tartu, Estonia \\ ${ }^{1}$ E-mail: karin.nurme@emu.ee; https://orcid.org/0000-0001-6563-8951 \\ 2E-mail:anne.must@emu.ee; https://orcid.org/0000-0002-0185-8573 \\ ${ }^{3}$ E-mail:enno.merivee@emu.ee; https://orcid.org/0000-0002-9521-783X
}

\begin{abstract}
Many aspects of ectothermic life are affected by external temperature conditions. Therefore, thermosensation and thermoregulation are crucial for survival of ground dwelling carabid beetles. Research in sensory physiology with Pterostichus oblongopunctatus has shown change in the reaction of antennal thermoreceptor neurons at temperatures above the $P$. oblongopunctatus's preferred temperature. From $25^{\circ} \mathrm{C}$, these neurons in dome shaped sensilla start to change from regular impulse firing to firing in bursts. We hypothesized that temperature-dependent impulse bursts are involved in P. oblongopunctatus's behavioural thermoregulation. Behavioural experiments were carried out on the arena inside an environmental test chamber, and in two different temperature conditions - one with linearly increasing temperature, and the other with constant temperature. The temperature was increased from $10{ }^{\circ} \mathrm{C}$ to $40{ }^{\circ} \mathrm{C}$ linearly during $50 \mathrm{~min}$ on first case and with 5 degree steps on second case with duration $50 \mathrm{~min}$ each step. Locomotion parameters (velocity and travelled distance) were measured using an automated video tracking system. We observed both low and high activity zones in P. oblongopunctatus. The threshold temperature for changing between zones occurred was at $25.8^{\circ} \mathrm{C}$. This indicates a link between spike burst of antennal thermoreceptor neurons and behavioural thermoregulation in P. oblongopunctatus.
\end{abstract}

Key words: Coleoptera, Carabidae, behavioural thermoregulation, locomotion parameters, peripheral spike bursting.

\section{INTRODUCTION}

АвRAм et al. (2016) proposed a unified framework to generalise temperature's effects on poikilothermic animals. The effects were divided into two categories: kinetic effects (temperature effect on physiology, a result of changes in biochemical reaction rates) and integrated effects (thermal information initiating behavioural modifications via the central nervous system). Despite the importance of the latter, the first one has been much better studied. Sensitivity to heat has been demonstrated in nearly all physiological systems in insects (e.g. metabolism, respiration, endocrine dynamics, reproduction, growth, and learning- and foraging behaviour (Neven 2000, AвrAm et al. 2016). Many 
ectotherms can adapt their physiology and behaviour to better tolerate their thermal environment (Stevenson 1985, Woods et al. 2015). Changes in behaviour are due to not only kinetic temperature effects (change in metabolism, e.g. flight muscles not working below certain temperature (LeHMAN 1999)), but also the integrated effects based on information gathered from the environment.

Of all the environmental abiotic factors, temperature and humidity are the most influential in governing habitat choice of carabid beetles (Coleoptera: Carabidae). Small arthropods such as carabids are vulnerable to desiccation and high temperature injury, the former being dangerous in much longer timeframes compared to the latter. In direct sunlight, due to infrared radiation, a $10 \mathrm{mg}$ insect can heat up almost instantaneously by $10{ }^{\circ} \mathrm{C}$ in $10 \mathrm{~s}$ (HeInRICH 1993). In Estonia during the summer the air temperature is $22{ }^{\circ} \mathrm{C}$, the soil surface temperature ranges from 16 to $55^{\circ} \mathrm{C}$ depending whether it is located in direct sunlight or shade (Must 2006). In carabid beetles, total heat paralysis begins at 47.4 to $51.7^{\circ} \mathrm{C}$, depending on species (Thiele 1977). In P. oblongopunctatus, the first indications of partial paralysis occur at $44.4{ }^{\circ} \mathrm{C}$ (Must et al. 2010). To survive, decisions must be made instantaneously and take into account information gathered from the environment.

Insects' external thermosensory organs (i.e. sensilla) are mostly located on antennae but can be also found on other parts of body (e.g. head, thorax, legs, ovipositor) (Altner \& Loftus 1985, Altner \& Prillinger 1980, Hess \& Loftus 1984, Ehn and Tichy 1996, Merivee et al. 2003, Ruchty et al. 2009, Wang et al. 2009). A triad of neurons, one temperature-sensitive and two antagonistic bimodal hygroreceptor neurons, typically innervate these type of sensilla (Waldow 1970, Tichy 1979, Altner et al. 1981, Yoконari et al. 1982, Altner \& Loftus 1985, Piersanti et al. 2011). The peripheral system's reaction to temperature is well studied in the carabid beetle P. oblongopunctatus (Nurme et al. 2015, Must et al. 2017) and the elaterid beetle Agriotes obscurus (Nurme et al. 2018). In both cases, the electrophysiological experiments with antennal dome shaped sensilla (DSS) demonstrated that, on the stressfully high temperatures (>25-30 ${ }^{\circ} \mathrm{C}$ ), the regular firing of antennal thermo- and bimodal hygrothermoreceptor neurons are overridden by firing in bursty manner. Several parameters of spike trains are temperature dependent, and it was hypothesised that spike bursts are responsible for detecting noxiously high temperatures. Indeed, in a behavioural experiment using $A$. obscurus, threshold temperature for elevation in locomotor activity (LA) coincided with spike bursting threshold temperature (Nurme et al. 2018). No comparable behavioural tests have been made in other insects. In this study we hypothesise that the link between spike bursting of the antennal DSS neurons and locomotion locomotion is widespread in insects by demonstrating its existence in carabids. We expect onset for elevated locomotor activity in P. oblongopunctatus in the range of 25 to $30^{\circ} \mathrm{C}$. 


\section{MATERIAL AND METHODS}

\section{Study insects}

The test carabid species of the study, $P$. oblongopunctatus, is common throughout the Palearctic (Löвl \& SMETANA 2003). We used individuals from a population in southern Estonia. This species is predominantly nocturnal (daytime activity of 30-45\%) (THIELE 1977), and its preferred temperatures lay between 10 and $25^{\circ} \mathrm{C}$ (Thiele 1977). P. oblongopunctatus is a forest generalist and tends to be euryhygric to dry-preferring (LindROTH 1986).

We collected adult beetles from their hibernation sites in late autumn 2015. Up to the time they were used in experiments, the beetles were kept at $5^{\circ} \mathrm{C}$ in $20 \times 30 \times 10 \mathrm{~cm}$ plastic boxes filled with moist pieces of brown-rotted wood and moss. Two days prior to the experiments, test beetles were kept at room temperature and fed with moistened commercial cat food (Friskies Vitality, Hungary)

\section{Test arena}

The test arena was a $27 \times 21 \times 10 \mathrm{~cm}$ plastic box with moistened quartz-sand lining. The arena was located inside an Environmental Test Chamber (Sanyo MLR-351H, SANYO Electric Co., Ltd., Japan) (10 to $40^{\circ} \mathrm{C}, \mathrm{RH} 55 \%$ ). The temperature model was double-checked with HygroPalm 3 (Rotronic AG, Switzerland). For illumination two compact fluorescent lamps OSRAM DULUX® S, 11W (OSRAM, Italy) were located $50 \mathrm{~cm}$ over arena and directed upwards to provide diffused illumination. Illumination on the arenas (20 lux) was measured by the Digital Light Meter TES-1335 (TES Electrical Electronic Corp., Taiwan). Video was recorded with computer-centred camera USB Webcams C120 (Logitech Inc., USA) fixed at the same height as the lamps.

\section{Procedure}

Two types of experiments were conducted: experiments with linearly changing temperature conditions and with constant temperature conditions. In the former the temperature program ran $50 \mathrm{~min}$, the temperature rising linearly at $0.6^{\circ} \mathrm{C}$ per min from $10{ }^{\circ} \mathrm{C}$ to 40 ${ }^{\circ} \mathrm{C}$ (figure 1A, B). The test beetles were introduced to the test arena $15 \mathrm{~min}$ before filming, when the test chamber was at $10^{\circ} \mathrm{C}$. This time allowed them settle down and become acquainted with the environment. This procedure was repeated with 12 beetles.

For the other experiments the temperature program was steady throughout the recording (50 min). Temperature was increased from 10, 15, 20, 25, 30, 35 and $40{ }^{\circ} \mathrm{C}$. The test beetles were introduced to the arena, and video-recording began $15 \mathrm{~min}$ after optimal temperature was reached. Four repetitions were performed for each temperature level. The temperature program and video-recording were started simultaneously. Deput Video Capture Software (NCH Software, USA) was used, with applied frame rate of 5 frames per second.

\section{Data management and statistical analysis}

A video tracking system (EthoVision XT 11, Noldus, Netherlands) was used for gathering data on activity parameters: total distance travelled, average distance travelled per minute, and mean- and top speed. Video was analyzed at 2.5 frames per second. 
Statistical analysis was carried out with $\mathrm{R}$ software, version 3.1.2 ( $\mathrm{R}$ Development Core Team, Austria), and package ade4 (Dray \& Dufour 2007) was used for principal component analysis.

\section{RESULTS}

\section{Linearly changing temperature conditions}

Patterns of LA of P. oblongopunctatus, in linearly changing temperature conditions, were characterized by low LA in the beginning of the experiment and elevated LA in the second part of the experiment, in the higher temperature zone. Activity patterns were distributed into two distinct categories. $42 \%$
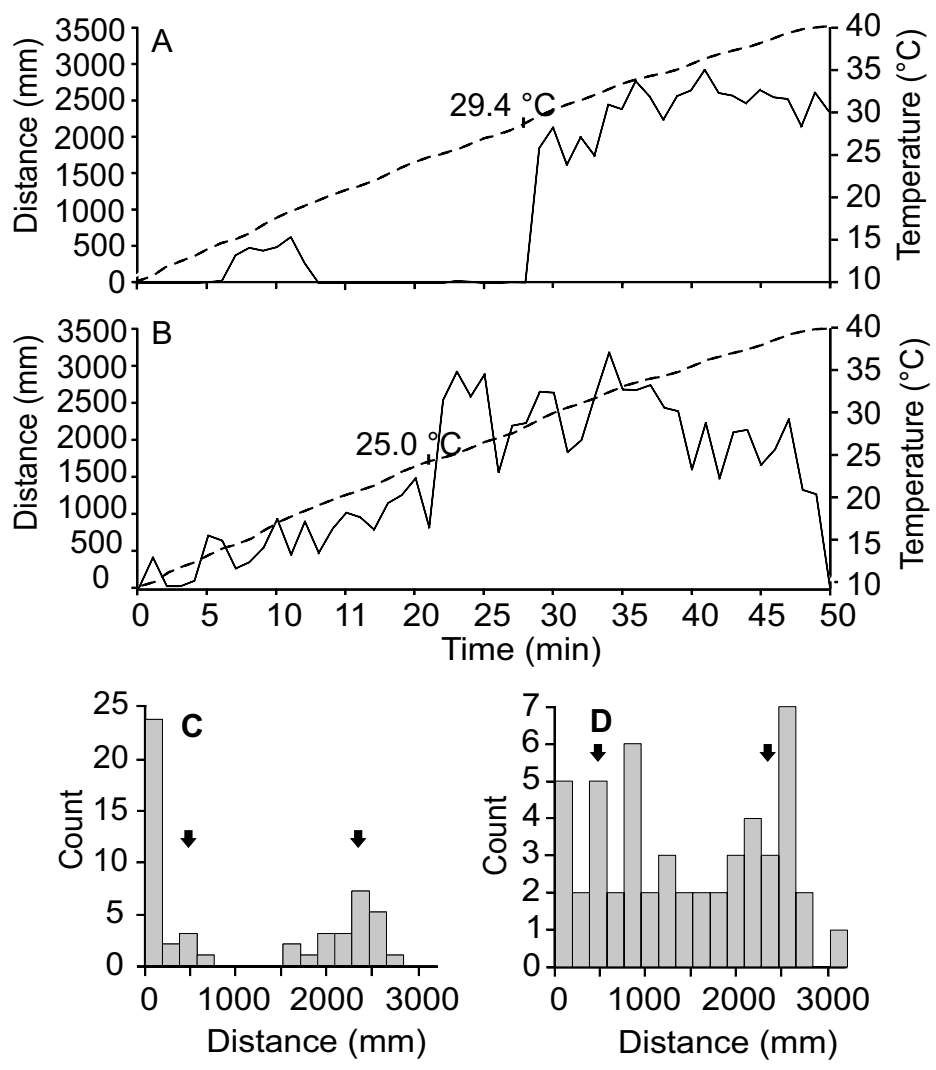

Fig. 1. Sample locomotor activity plots of $P$. oblongopunctatus in a linearly increasing temperature conditions ranged from $10-40^{\circ} \mathrm{C}(\mathrm{A}, \mathrm{B})$. Displayed temperatures are the threshold temperatures where the locomotor activity of the beetle changed rapidly from low to high. The travelled distance histograms (C, D) were constructed to determine the threshold temperatures. Two maxima show distinct difference in the travelled distance. Left and right maximum show low and high locomotor activity, respectively 
of the data are described by pattern on sample recording on Figure $1 \mathrm{~A}$, where in the first half the beetle mainly stood still and the $58 \%$ of the data are described by pattern on sample recording on figure $1 \mathrm{~B}$, where the beetle are active throughout the experiment, but less active in the first half, on lower temperature zone. Temperature where the change occurs was determined with the travelled distance histograms (Figs 1C, 1D). Two maxima show a distinct difference in distance travelled. Left and right maximum show low and high $\mathrm{LA}$, respectively. The average threshold temperature was $25.83^{\circ} \mathrm{C}$.
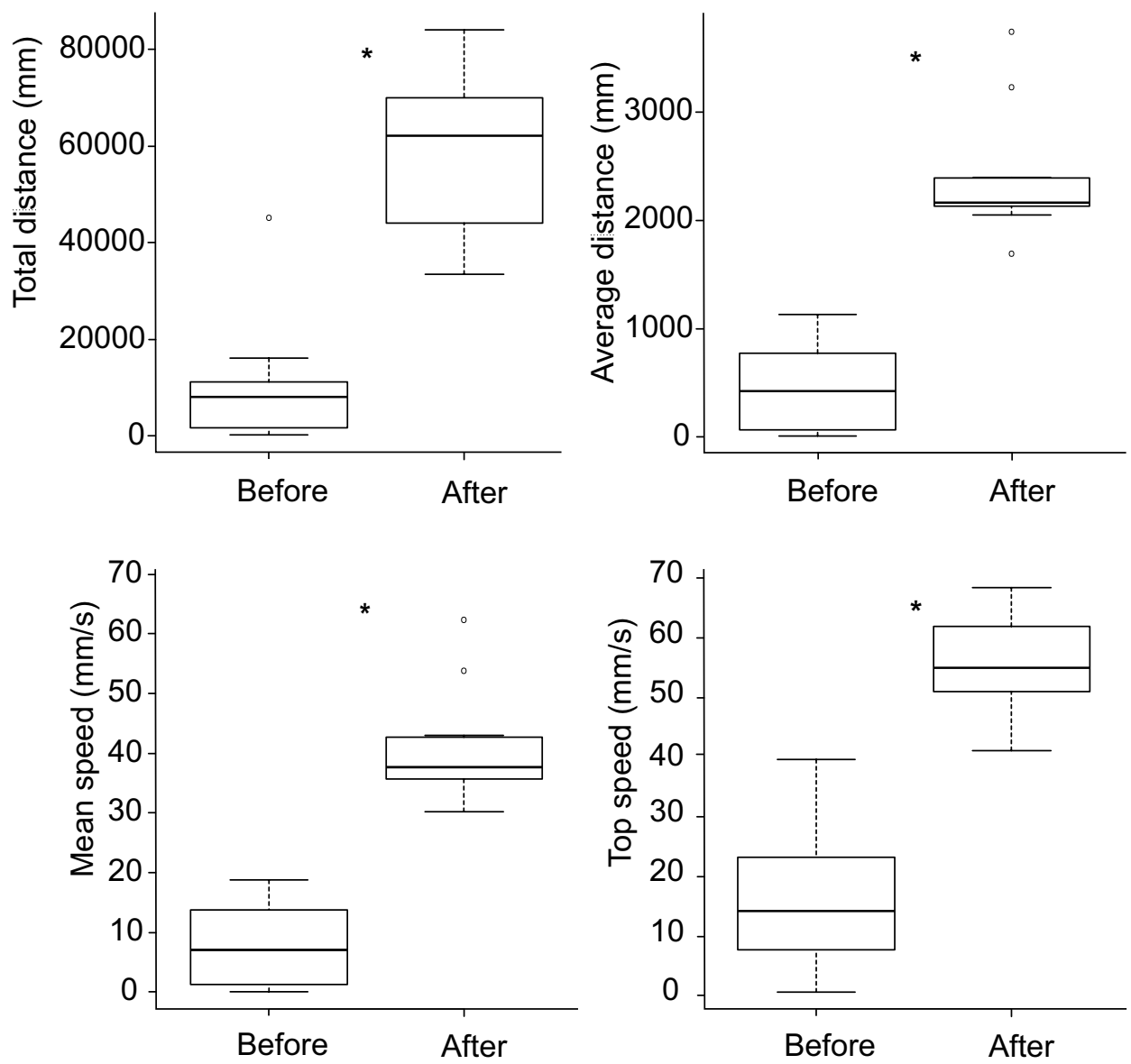

Fig. 2. Parameters describing the beetles' movement in low and high activity zones (A - D). The zones are defined by threshold temperatures, which is identified as point in temperature scale where level of activity promptly changes. The box and horizontal bar within represent the interquartile range and median of the parameters, respectively. The whiskers extend to the most extreme data point, which is no more than 1.5 times the interquartile range from the box. Dots represent outliers. Significant comparisons, as revealed in twosided Wilcoxon rank sum test, are depicted by “*” $(\mathrm{p}<0.001)$ 
Measured LA parameters showed a distinct difference before and after threshold temperature (Wilcoxon Rand Sum Test, $\mathrm{p}<0.001$ ). Median of total distance moved per minute increased 7.75 times, being $8009.76 \mathrm{~mm}$ in the low activity zone and $62057.12 \mathrm{~mm}$ in the high activity zone. A 5.1-fold increase in average distance travelled, from $421.57 \mathrm{~mm}$ to $2161.13 \mathrm{~mm}$, was observed. In addition, both mean and top speed increased with temperature increase from $7.03 \mathrm{~mm} / \mathrm{s}$ to $37.58 \mathrm{~mm} / \mathrm{s}$ and from $14.25 \mathrm{~mm} / \mathrm{s}$ to $54.95 \mathrm{~mm} / \mathrm{s}$, respectively, a 5.3 and 3.9-fold rise.

\section{Different levels of steady temperature conditions}

To analyse the main tendencies between activity parameters and temperature levels, a principal component analysis (PCA) was performed. Results of the PCA indicated a strong correlation between total distance and mean speed at: $10,15,20$, and $40{ }^{\circ} \mathrm{C}$; and 25,30 , and $35^{\circ} \mathrm{C}$. The two temperature groups were poorly correlated (Fig. 3). The first two axes explain $90.58 \%$ of the variation $(84.96 \%$ and $5.62 \%$ for PC1 and PC2, respectively).

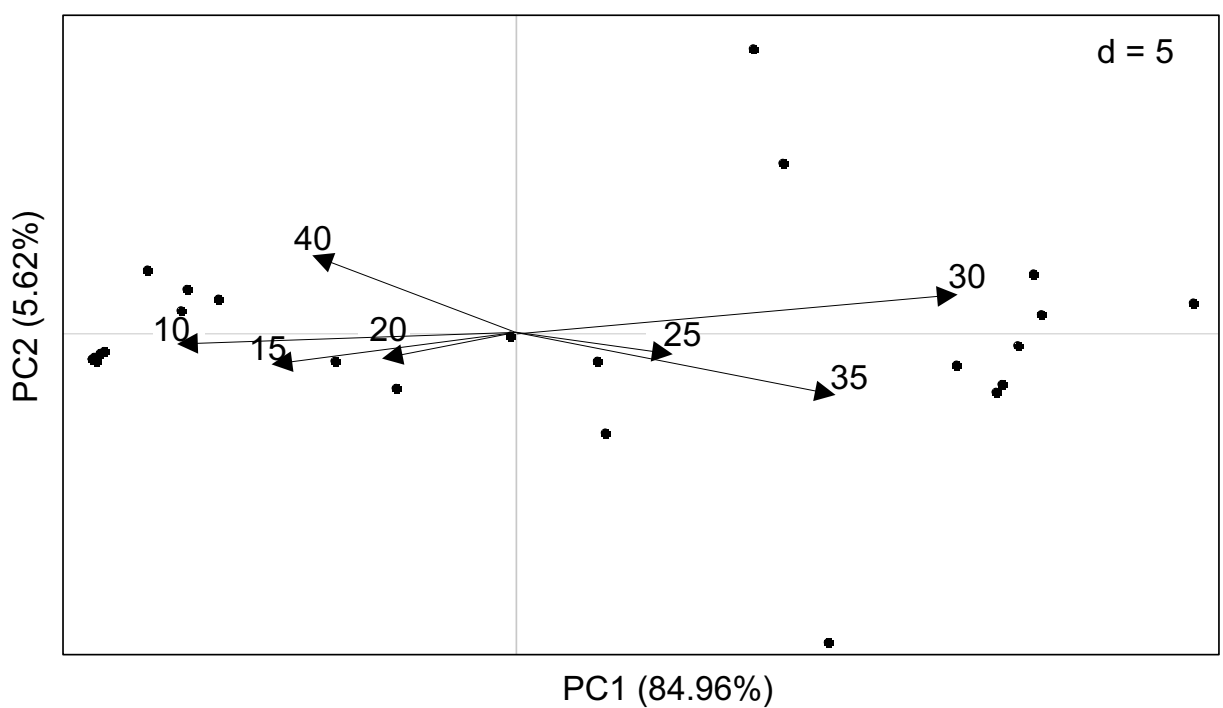

Fig. 3. Principal component analysis (PCA) of locomotion parameters data. The biplot shows the correlation between the distance travelled and mean speed (scores) as dots and temperature effect (loadings) as vectors. Vectors that are close together are highly correlated, while vectors that are orthogonal are poorly correlated. The length of a vector is proportional to the importance of the descriptor to the sites 


\section{DISCUSSION}

In laboratory behavioural tests, we observed tranquil LA in the lower temperature zone and elevated LA in stressful temperature zone of $P$. oblongopunctatus, with an average threshold temperature of $25.83{ }^{\circ} \mathrm{C}$. The threshold temperature for activity change coincided with the end of the preference temperature zone, which is in agreement with Thiele (1977). Similar results were found on A. obscurus, LA patterns being the same, but the threshold temperature for elevated LA was ca $2{ }^{\circ} \mathrm{C}$ higher $\left(27.5 \pm 0.75{ }^{\circ} \mathrm{C}\right)$ (Nurme et al. 2018). The $2{ }^{\circ} \mathrm{C}$ difference could be explained with different habitat preference, $P$. oblongopunctatus being a forest species and A. obscurus preferring fields.

Often species have an optimal or preferred temperature zone, where the performance curve maximum lies (EsterhuIZEN et al. 2014, KJAERSGAARD et al. 2015, Schou et al. 2013, Hough-Goldstein et al. 2016). By contrast, animal's spontaneous locomotor activity remains low at their preferred temperatures until they do not have the need to move (BAYLEY 2002). Our results showed that in P. oblongopunctatus, low spontaneous locomotion zone lay in the range of 10 to $20^{\circ} \mathrm{C}$ well coinciding with its preferred temperature range of 10 to $25{ }^{\circ} \mathrm{C}$ (THiele 1977). In the possibly dangerous temperatures they start to look for way out (avoidance behaviour), remaining active as long as possible (KJaersgaard 2010, Stevenson 1985).

At unfavourably high temperatures $\left(\geq 40^{\circ} \mathrm{C}\right)$, we observed LA declines in $P$. oblongopunctatus. Reduced locomotion at very high temperatures has been observed in many insect species (KJAersgaARd 2010, Uyi 2017, Woods 2015, Dillon et al. 2012, Anderson et al. 2007). KJaersgaArd (2010) proposed that "a possible explanation for this could be that the exposure is so severe that any effect of thermal adaptation is effectively overridden by high thermal instability of the cells and membranes compromising the locomotor system and survival".

Behavioural regulation of body temperature is established via selection of preferred temperatures initiated by the peripheral nervous system. Each nervous signal carries on information from the environment. Previous electrophysiological experiments with $P$. oblongopunctaus have also shown that at $25-30{ }^{\circ} \mathrm{C}$ thermosensitive neurons start to switch from regular neuroimpulse firing to burst-like firing (Nurme et al. 2015, Must et al. 2017). Thus, according to our hypothesis, in P. oblongopunctatus, the threshold temperatures for elevated locomotion $\left(25.83{ }^{\circ} \mathrm{C}\right)$ and neuronal spike bursting well coincide. Burstiness of neurons have been shown in many sensory systems, from mammalian (Dykes 1975, Sherman 2001, Gallar et al. 2003) to insect (Orthoptera) auditory (Marsat \& Pollack 2006, Eyherabide et al. 2008, Triblehorn \& Jager 2005) and visual systems (McMillan \& Gray 2015). In the case of insects, it 
has been clearly shown that bursts of the neurons initiate strong behavioural responses, while firing in a regular manner does not. In addition, the timing of the burst is a key to looming destiny, burstiness of the spike trains increases with information relevance. Therefore, the bursts are catalysts of escape behaviour - predator evasion, collision avoidance, etc. In this study, we show that the threshold temperatures for spike bursting of the thermosensitive neurons in dome shaped sensilla coincide with elevated mobility of the P. oblongopunctatus. This suggests that the spike bursts are responsible for encoding stressfully high ambient temperatures, inducing escape behaviour in beetles to avoid overheating.

Acknowledgements - The Development Fund of the Estonian University of Life Sciences 8PM170157PKTK and Institutional Research Funding IUT36-2 of the Estonian Ministry of Education and Research supported the study. Proofreading of the manuscript were done by Jonathan Willow.

\section{REFERENCES}

Aвram, P. K., Boivin, G., Moiroux, J., Brodeur, J. (2016): Behavioural effects of temperature on ectothermic animals: unifying thermal physiology and behavioural plasticity. Biological Reviews 92(4): 1859-1876. https://doi.org/10.1111/brv.12312

Altner, H. \& Prillinger, L. (1980): Ultrastructure of invertebrate chemo- thermo-, and hygroreceptors and its functional significance. - International Review of Cytology 67: 69-139. https://doi.org/10.1016/S0074-7696(08)62427-4

Altner, H., Routil, C. \& Loftus, R. (1981): The structure of bimodal chemo-, thermo-, and hygroreceptive sensilla on the antenna of Locusta migratoria. - Cell and Tissue Research 215: 289-308. https://doi.org/10.1007/BF00239116

Altner, H. \& Loftus, R. (1985): Ultrastructure and function of insect thermo-and hygroreceptors. - Annual Review of Entomology 30: 273-295. https://doi.org/10.1146/annurev. en.30.010185.001421

Anderson, J. L., Albergotti, L., Proulx, S., Peden, C., Huey, R. B. \& Phillips, P. C. (2007): Thermal preference of Caenorhabditis elegans: a null model and empirical tests. Journal of Experimental Biology 210: 3107-3116. doi: 10.1242/jeb.007351

Dillon, M. E., Liu, R., Wang, G. \& Huey, R. B. (2012): Disentangling thermal preference and the thermal dependence of movement in ectotherms. - Journal of Thermal Biology 37: 631-639. https://doi.org/10.1016/j.jtherbio.2012.07.004

Dray, S. \& Dufour, A. B. (2007): The ade4 package: implementing the duality diagram for ecologists. - Journal of Statistical Software 22(4): 1-20. https://doi.org/10.18637/jss.v022. i04

Dykes, R. W. (1975): Coding of steady, transient temperatures by cutaneous "cold" fibers serving the hand of monkeys. - Brain Research 98(3): 485-500. https://doi. org/10.1016/0006-8993(75)90368-6 
EнN, R. \& Tісну, H. (1996): Response characteristics of a spider warm cell: temperature sensitivities and structural properties. - Journal of Comparative Physiology A 178(4): 537-542. https://doi.org/10.1007/BF00190183

Esterhuizen, N., Clusella-Trullas, S., van Daalen, C. E., Schoombie, R. E., Boardman, L. \& Terblanche, J. S. (2014): Effects of within-generation thermal history on the flight performance of Ceratitis capitata: colder is better. - Journal of Experimental Biology 217: 3545-3556. https://doi.org/10.1242/jeb.106526

Eyherabide, H. G., Rokem, A., Herz, A. V. M. \& Samengo, I. (2008): Burst firing is a neural code in an insect auditory system. - Frontiers in Computational Neuroscience 2: 3. https://doi.org/10.3389/neuro.10.003.2008

Gallar, J., Acosta, M. C. \& Belmonte, C. (2003): Activation of scleral cold thermoreceptors by temperature and blood flow changes. - Investigative Ophthalmology E Visual Science 44: 697-705. https://doi.org/10.1167/iovs.02-0226

HeInRICH, B. (1993): The hot-blooded insects: strategies and mechanisms of thermoregulation. Springer, Berlin, $601 \mathrm{pp}$.

Hess, E. \& Loftus, R. (1984): Warm and cold receptors of two sensilla on the foreleg tarsi of the tropical bont tick Amblyomma variegatum. - Journal of Comparative Physiology A 155: 187-195. https://doi.org/10.1007/BF00612636

Hough-Goldstein, J., Lake, E. C., Shropshire, K. J., Moore, R. A. \& D’Amico, V. (2016): Laboratory and field-based temperature dependent development of a monophagous weevil: implications for integrated weed management. - Biological Control 92: 120127. http://dx.doi.org/10.1016/j.biocontrol.2015.10.009

KJersgaard, A., Blanckenhorn, W. U., Pertoldi, C., Loeschcke, V., Kaufmann, C., Hald, B., PAgÈs, N. \& BAhrndorfF, S. (2015): Plasticity in behavioural responses and resistance to temperature stress in Musca domestica. - Animal Behaviour 99: 123-130. http:// dx.doi.org/10.1016/j.anbehav.2014.11.003

Kjærsgaard, A., Demontis, D., Kristensen, T. N., Le, N., Faurby, S., Pertoldi, C., et al. (2010): Locomotor activity of Drosophila melanogaster in high temperature environments: plastic and evolutionary responses. - Climate Research 43:127-134. http:// dx.doi.org/10.1016/j.anbehav.2014.11.003

Lehmann, F. O. (1999): Ambient temperature affects free-flight performance in the fruit fly Drosophila melanogaster. - Journal of Comparative Physiology B 169(3): 165-171. https://doi.org/10.1007/s003600050207

Lindroth, C. H., (1985): The Carabidae (Coleoptera) of Fennoscandia and Denmark. - Fauna Entomologica Scandinavica 15(2): 233-497.

Löвl, I. \& Smetana, A. (2003): Catalogue of Palaearctic Coleoptera. Vol 1: Archostemata, Myxophaga, Adephaga. - Apollo Books, Stenstrup, 819 pp.

Marsat, G., \& Pollack, G. S. (2006): A behavioural role for feature detection by sensory bursts. - Journal of Neuroscience 26: 10542-10547. https://doi.org/10.1523/jneurosci.2221-06.2006

McMillan, G. A., \& GRAY, J. R. (2015): Burst firing in a motion-sensitive neural pathway correlates with expansion properties of looming objects that evoke avoidance behaviors. - Frontiers in Integrative Neuroscience 9: 60. https://doi.org/10.3389/fnint.2015.00060

Merivee, E., Vanatoa, A., Luik, A., Rahi, M., Sammelselg, V. \& Ploomi, A. (2003): Electrophysiological identification of cold receptors on the antennae of the ground beetle Pterostichus aethiops. - Physiological Entomology 28: 88-96. https://doi.org/10.1046/ j.1365-3032.2003.00320.x 
Must, A., Merivee, E., Mänd, M., Luik, A. \& HeidemaA, M. (2006): Electrophysiological responses of the antennal campaniform sensilla to rapid changes of temperature in the ground beetles Pterostichus oblongopunctatus and Poecilus cupreus (Tribe Pterostichini) with different ecological preferences. - Physiological Entomology 31: 278-28. https://doi.org/10.1111/j.1365-3032.2006.00518.x

Must, A., Merivee, E., Luik, A., Williams, I., Ploomi, A. \& HeidemaA, M. (2010): Spike bursts generated by the thermosensitive (cold) neuron from the antennal campaniform sensilla of the ground beetle Platynus assimilis. - Journal of Insect Physiology 56: 412-421. https://doi.org/10.1016/j.jinsphys.2009.11.017

Must, A., Merivee, E., Nurme, K., Sibul, I., Muzzi, M., Di Giulio, A., Williams, I. \& ToomING, E. (2017): Encoding noxious heat by the antennal bimodal hygroreceptor (dry) neurons in the carabid Pterostichus oblongopunctatus. - Cell and Tissue Research 368(1): 29-46. https://doi.org/10.1007/s00441-016-2547-y

Neven, L. G. (2000): Physiological responses of insects to heat. - Postharvest Biology and Technology 21: 103-111. https://doi.org/10.1016/S0925-5214(00)00169-1

Nurme, K., Merivee, E., Must, A., Sibul, I., Muzzi, M., Di Giulio, A., Williams, I. \& ToomING, E. (2015): Responses of the antennal bimodal hygroreceptor neurons to innocuous and noxious high temperatures in the carabid beetle, Pterostichus oblongopunctatus. - Journal of Insect Physiology 81: 1-13. https://doi.org/10.1016/j.jinsphys.2015.06.010

Nurme, K., Merivee, E., Must, A., Di Giulio, A., Muzzi, M., Williams, I. \& Mänd, M. (2018): Bursty spike trains of antennal thermo- and bimodal hygro-thermoreceptor neurons encode noxious heat in elaterid beetles. - Journal of Thermal Biology 72: 101117. https://doi.org/10.1016/j.jtherbio.2018.01.008

Piersanti, S., Rebora, M., Almaas, T. J., Salerno, G. \& Gaino, E. (2011): Electrophysiological identification of thermo- and hygro-sensitive receptor neurons on the antennae of the dragonfly Libellula depressa. - Journal of Insect Physiology 57: 1391-1398. https:// doi.org/10.1016/j.jinsphys.2011.07.005

Ruchty, M., Romani, R., Kuebler, L. S., Ruschioni, S., Roces, F., Isidoro, N. \& Kleineidam, C. J. (2009): The thermo-sensitive sensilla coeloconica of leaf-cutting ants (Atta vollenweideri). - Arthropod Structure \& Development 38: 195-205. https://doi.org/10.1016/j. asd.2008.11.001

Schou, T. M., Faurby, S., KJÆrgsaard, A., Pertoldi, C., Loeschcke, V., Hald, B. \& BahRNDORFF, S. (2013): Temperature and population density effects on locomotor activity of Musca domestica (Diptera: Muscidae). - Entomological Society of America 42(6): 1322-1328. https://doi.org/10.1603/EN13039

Sherman, S. M. (2001): Tonic and burst firing: dual modes of thalamocortical relay. - Trends Neuroscience 24: 122-126. https://doi.org/10.1016/s0166-2236(00)

Stevenson, R. D. (1985): The relative importance of behavioural and physiological adjustments controlling body temperature in terrestrial ectotherms. - The American Naturalist 126(3): 362-386. https://doi.org/10.1086/284423

Thiele, H. U. (1977): Carabid beetles in their environment. - Zoophysiology and Ecology, vol. 10. Springer, Berlin. https://doi.org/10.1007/978-3-642-81154-8

Тісну, Н. (1979): Hygro- and thermoreceptive triad in antennal sensillum of the stick insect, Carausius morosus. - Journal of Comparative Physiology 132(2): 149-152. https:// doi.org/10.1007/BF00610718

Тісну, Н. (1987): Hygroreceptor identification and response characteristics in the stick insect Carausius morosus. - Journal of Comparative Physiology A 160(1): 43-53. https:// doi.org/10.1007/BF00613440 
Triblehorn, J. D. \& YAger, D. D. (2005): Timing of praying mantis evasive responses during simulated bat attack sequences. - Journal of Experimental Biology 208: 1867-1876. https://doi.org/10.1242/jeb.01565

Uyi, O. O., Zachariades, C., Marais, E. \& Hill, M. P. (2017): Reduced mobility but high survival: thermal tolerance and locomotor response of the specialist herbivore, Pareuchaetes insulata (Walker) (Lepidoptera: Erebidae), to low temperatures. - Bulletin of Entomological Research 107: 448-457. https://doi.org/10.1017/S0007485316001103

WALDow, U. (1970): Elektrophysiologische Untersuchungen an Feuchte-, Troken- und Kälterezeptoren auf der Antenne der Wanderheuschrecke Locusta. - Zeitschrift für vergleichende Physiologie 69(3): 249-283. https://doi.org/10.1007/BF00297962

Wang, G., Qiu, Y., Lu, T., Kwon, H. W., Pitts, R., van Loon, J., Takken, W. \& Zwiebel, L. J. (2009): Anopheles gambiae TRPA1 is a heat-activated channel expressed in thermosensitive sensilla of female antennae. - European Journal of Neuroscience 30(6): 967-974. https://doi.org/10.1111/j.1460-9568.2009.06901.x

Woods, H. A., Dillon, M. E. \& Pincebourde, S. (2015): The roles of microclimatic diversity and of behaviour in mediating the responses of ectotherms to climate change. - Journal of Thermal Biology 54: 86-97. https://doi.org/10.1016/j.jtherbio.2014.10.002

Yoконari, F., Tominaga, Y. \& Tateda, H. (1982): Antennal hygroreceptors of the honeybee, Apis mellifera L. - Cell and Tissue Research 226(1): 63-73. https://doi.org/10.1007/ BF00217082

Received October 15, 2018, accepted January 1, 2019, published November 22, 2019 
